\title{
SYNERGISTIC EFFECT OF NANO ZERO-VALENT IRON AND CYCLODEXTRINS: A NANO-STRUCTURE FOR WATER PURIFICATION
}

\author{
Kamil KRAWCZYK, Stanisław WACŁAWEK, Daniele SILVESTRI, \\ Rafael TORRES-MENDIETA, Vinod V.T. PADIL, Michal ŘEZANKA, Miroslav ČERNÍK \\ Centre for Nanomaterials, Advanced Technologies and Innovation, Technical University of Liberec, \\ Liberec, Czech Republic, EU, +420 485353 006, \\ stanislaw.waclawek@tul.cz
}

https://doi.org/10.37904/nanocon.2019.8575

\begin{abstract}
Nanoscale zero-valent iron (NZVI) is one of the most important nanostructure for degradative remediation of environmental contaminants. In our research, NZVI was for the first time functionalized with cyclodextrins (CD), recently considered as excellent, environmentally friendly and cheap absorbents of toxic pollutants. Functionalization of the nano zero-valent iron by $C D$, their derivatives and polymers, can not only improve the ZVI nanoparticles stability and dispersibility, but also can complex toxic contaminants inside the CD cavities that will be further reduced by NZVI to a less toxic products. By this, one of the largest obstacles in the NZVI field i.e. lack of NZVI selectivity could be overcome. Moreover, reactivity towards a recalcitrant non-polar compound, that under standard conditions is not very reactive with the NZVI alone, has been shown herein.
\end{abstract}

Keywords: Nanoparticles, NZVI, cyclodextrins, water treatment, surface modification

\section{INTRODUCTION}

The wide range of persistent contaminants including inorganic and organic pollutants [1] in ground and surface waters is becoming more problematic due to, among others, rapid development of industrialization [2]. The constant need for clean water supply urges development of innovative methods for purification and treatment of water and wastewater. On the other hand, advancing technologies based on nanomaterials brought evolution to wide array of technologies in environmental, industrial and domestic applications, including new methods for water remediation [3] and improved drug delivery [4]. Nanoparticles in particular have received a significant attention due to the unique properties such as catalytic, magnetic, chemical and optical capabilities. Their enhanced catalytic activity comes from small size, meaning high specific surface area that improves the tendency to interact, adsorb and react with toxic contaminants [5]. Therefore, their potential use in wastewater treatment has sparked a great deal of interest.

In the last twenty years, nanoscale zero-valent iron particles (NZVI) have been promising topic for groundwater remediation. NZVI was reported to be effective at degradation of contaminants such as: nitrates, heavy metals, phenols, almost all chlorinated solvents, pesticides, azo dyes and pharmaceutical pollutants [6-9] NZVI is also effective in immobilization of inorganic anions like chromium or arsenic and in recovery or removal of dissolved metals from the solution [10-12]. One of the main reasons why NZVI is used for remediation is due to their high specific surface area that allows for better accessibility to the NZVI surface and hence improved catalytic activity [13]. However, there are several key limitations for application of NZVI, such as restricted mobility, stability and selectivity (it tends to react with water instead of contaminants of concern). Moreover, their strong tendency to aggregate in aqueous environment results in lower specific surface area which can result in reduced catalytic reactivity [14]. To overcome these problems, many studies have proposed the modification of NZVI surface by using polymers (e.g. guar gum, gum karaya, chitosan and many others [15-17]), improving their dispersibility, stability and mobility in porous media $[18,19]$. 
$\beta$-Cyclodextrins $(\beta C D)$ are cyclic oligosaccharides with seven glucose units and are biodegradable [20]. Hydrophilic external surface of $\beta C D$ makes them water-soluble [21], whereas their hydrophobic cavity, allows them to form host-guest inclusion complexes in which an organic guest can be sequestered [22]. In the literature it is reported that cyclodextrins can form moderately stable complexes with some classes of pollutants i.e. phthalic acid esters, chlorinated biphenyls or PAHs [23-25].

In this work, for the first time NZVI particles were synthesized together with $\beta C D$. Thus synthesized nanoparticles ( $\beta C D-N Z V I)$ were characterized by several techniques by which we have determined their morphology and surface properties. $\beta C D-N Z V I$ composite was further used for the reduction of 4-nitrophenol (4-NP) to 4-aminophenol (4-AM). $\beta C D-N Z V I$ has shown enhanced performance in reductive degradation of 4nitrophenol compared to the NZVI without stabilization.

\section{MATERIALS AND METHODS}

\subsection{Chemicals}

Iron (III) chloride hexahydrate ( $\geq 98 \%$, chunks), sodium borohydride ( $\geq 99 \%$, granular), 4-nitrophenol ( $\geq 99 \%)$, $\beta$-cyclodextrin ( $\geq 97 \%)$ were purchased from Sigma-Aldrich, Czech Republic. Sodium hydroxide $(\geq 98 \%)$ was purchased from LACH-NER, s.r.o., Czech Republic. Deionized water (18.2 M $\Omega \cdot \mathrm{cm}-1$, ELGA, Veolia Water, Marlow, UK) was used in all experiments.

\subsection{Analytical}

Scanning electron microscope (UHR FE-SEM Carl Zeiss ULTRA Plus, Germany) was used to study the nanoparticles morphology, operating at acceleration voltage $0.5-2.5 \mathrm{kV}$. Energy-dispersive X-ray spectroscopy analysis was made to evaluate presence of different elements. Zetasizer ZS (Malvern Instruments Ltd, UK) was used for measuring the zeta potential with autocorrelation functions of 10 seconds. Triplicate measurements were taken, prepared in freshly suspension and each result was the average of triplicate.

\subsection{Synthesis of iron nanoparticles with $\beta C D$}

The synthesis of $\beta C D-N Z V I$ was performed in accordance with a modified method previously reported by Wang, et al. [26], who has synthesized iron(II,III) oxide with $\beta C D$. Briefly, $100 \mathrm{~mL}$ solution of iron (III) chloride hexahydrate $(0.02 \mathrm{M})$ and $\beta C D(0.03 \mathrm{M}$; i.e. molar ratio of iron (III) chloride hexahydrate: $\beta C D-1: 1.5)$ was created. First $\beta C D$ was solubilized by stirring under $60^{\circ} \mathrm{C}(200 \mathrm{rpm})$, and then iron (III) chloride hexahydrate solution was added dropwise and the solution was stirred for additional 15 minutes under the nitrogen atmosphere. After that time, $10 \mathrm{~mL}$ of $\mathrm{NaBH}_{4}(1 \mathrm{M})$ was added dropwise and left for additional stirring for 10 minutes. Then synthesized nanoparticles were washed with ethanol 3 times and separated by a strong magnet (MAGSY s.r.o., Czech Republic). Finally, the nanoparticles were freeze-dried and kept for further use. The same procedure was used for other synthesis reported in this work.

\subsection{Remediation test}

The remediation test for the reduction of 4-nitrophenol (4-NP) was carried out in $10 \mathrm{~mL}$ bottle. Based on a procedure of Baruah, et al. [27]. Following conditions were applied: $0.1 \mathrm{~mL}$ of $\mathrm{NaOH}(1 \mathrm{M})$ was added to 4-NP stock solution $(10 \mathrm{~mL})$ then $240 \mu \mathrm{L}$ of $4-\mathrm{NP}(5 \mathrm{mM})$ was added to reactor and mixed along with a certain amount of $\beta C D-N Z V I$, rest of the volume was adjusted with DI water. Then, $1 \mathrm{~mL}$ of the sample was taken from the solution, filtered (CHS filterpure syringe filters $0.22 \mu \mathrm{m}$ ) and immediately transferred to a $1 \mathrm{~cm}$ quartz cuvette. Absorbance measurements were recorded by a UV-Vis spectrophotometer (Hach Lange DR 3900) at the wavelength of $401 \mathrm{~nm}[28]$. 


\section{RESULTS AND DISCUSSION}

\subsection{Morphology of $\beta C D-N Z V I$}

To study the structure and shape of the synthesized nanoparticles in this work, SEM analysis was made (Figure 1).
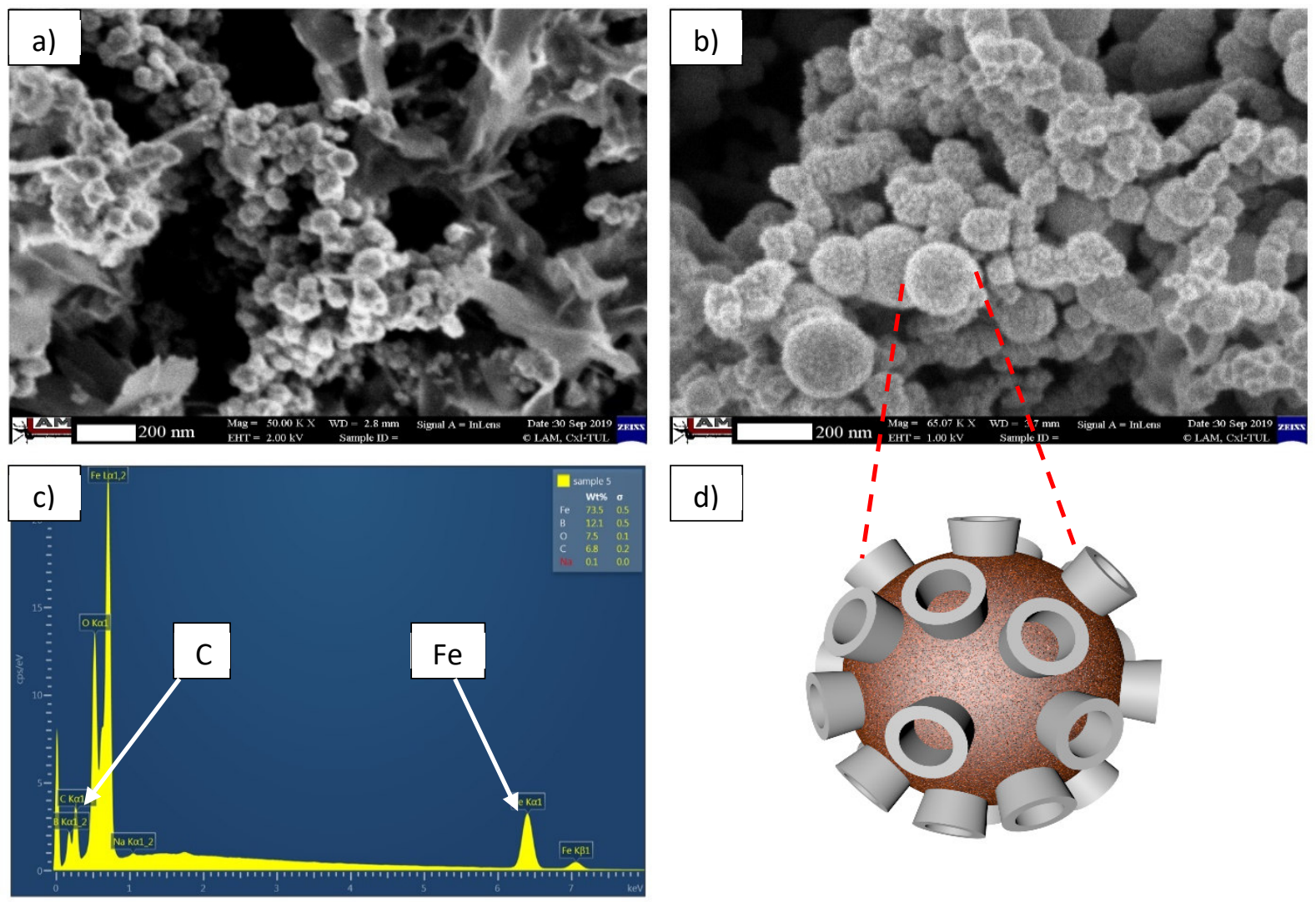

d)

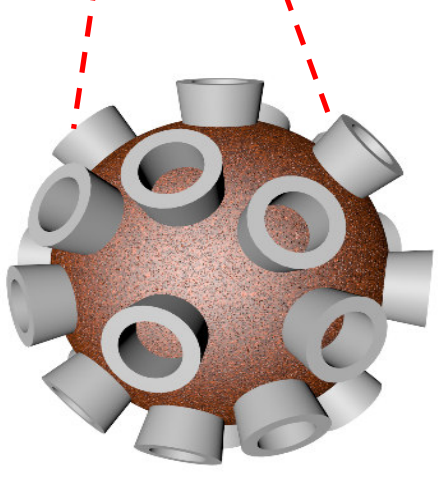

Figure 1 SEM images of a) bare NZVI and b) $\beta C D-N Z V I$ particles; c) EDX spectrum of $\beta C D-N Z V I$ and d) 3D model of $\beta C D-N Z V I$ composite

Bare NZVI (Figure 1a) exhibits a quasi-spherical shape due to the oxidation of NZVI, and its morphology is in accordance with our previous reports [15]. The synthesized $\beta C D-N Z V I$ (Figure 1b) are also spherical with a visible organic layer at the surface. This has been also further validated by EDX analysis (Figure 1c), which confirmed the presence of carbon and oxygen on the NZVI surface. Presence of both elements could indicate a $\beta C D$ layer on the NZVI. A 3D model of (as expected) $\beta C D-N Z V I$ was also created herein (Figure 1d). Based on the SEM analysis, particle size distribution was made for both NZVI and $\beta C D-N Z V I$ using ImageJ program. Average particles size distribution was found to be 155 and $86 \mathrm{~nm}$ for $\beta C D-N Z V I$ and bare NZVI, respectively.

\subsection{Zeta potential analysis}

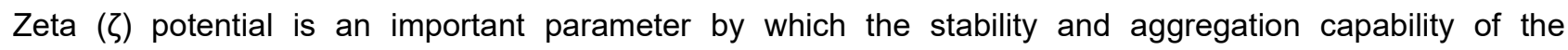
nanoparticles can be assessed [29]. The zeta potential values of nanoparticles typically range from $-100 \mathrm{mV}$ to $+100 \mathrm{mV}$. Moreover, they could indicate the interactions between the nanoparticles also revealing their aggregation. In accordance with literature the $\zeta$-potential above $30 \mathrm{mV}$ produces a good stability [30,31] while around $20 \mathrm{mV}$ gives only a short-term stability and values between $+5 \mathrm{mV}$ to $-5 \mathrm{mV}$ indicate fast aggregation [32]. Alterations in the $\mathrm{pH}$ have a significant effect on zeta potential of the particles and agglomerate size, 
changing the $\mathrm{pH}$ of the medium in which the nanoparticle is suspended will result in differences in the surface chemistry of a nanoparticle [33]. Not surprisingly, the values of $\zeta$-potential for $\beta C D-N Z V I$ varied depending on the $\mathrm{pH}$ value (Figure 2).

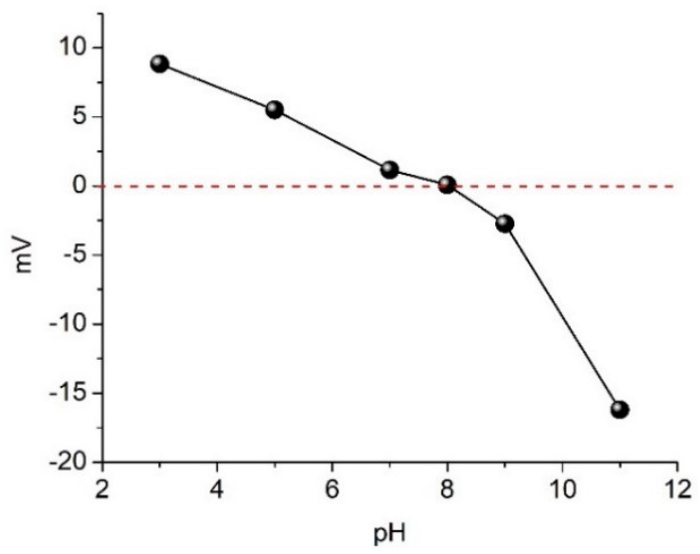

Figure 2 Zeta potential of $\beta C D-N Z V I$ (ratio $1: 1.5$ ) in different $\mathrm{pH}$ conditions

In more acidic conditions, $\zeta$-potential was around $+9 \mathrm{mV},+5 \mathrm{mV}$ for $\mathrm{pH} 3$ and 5 respectively. Under more neutral conditions $(\mathrm{pH} 7,8)$ the values oscillated near +1 and $0 \mathrm{mV}$. The isoelectric point (IEP) for synthesized $\beta C D-N Z V I$ was determined to be at the $\mathrm{pH}$ 8. Measured $\zeta$-potential is only negative when $\mathrm{pH}$ is higher than IEP since for $\mathrm{pH} 9$ and 11 , it was $-2.5 \mathrm{mV}$ and $-16 \mathrm{mV}$ respectively. Nanoparticles suspended in solutions with neutral $\mathrm{pH}$ could aggregate; however, in more acidic and alkaline conditions they could be more stable.

\subsection{Remediation tests}

4-NP was selected as a model pollutant since it is one of the most used chemicals for leather preservatives, drugs synthesis, pesticides and nitroaromatic compound production [34-37]. Due of its toxicity especially for bacteria, plants and humans [38-41] it is not surprising that 4-NP is commonly used as a model contaminant for catalytic studies [42-44]. 4-NP has the highest absorption peak at $\sim 317 \mathrm{~nm}$, by adding $\mathrm{NaOH}(1 \mathrm{M})$ the absorption peak shifts to $401 \mathrm{~nm}$, due to the deprotonation and formation of 4-nitrophenolate. Synthesized $\beta C D-N Z V I$ was tested for the hydrogenation of 4-NP to 4-AP (Figure 3).

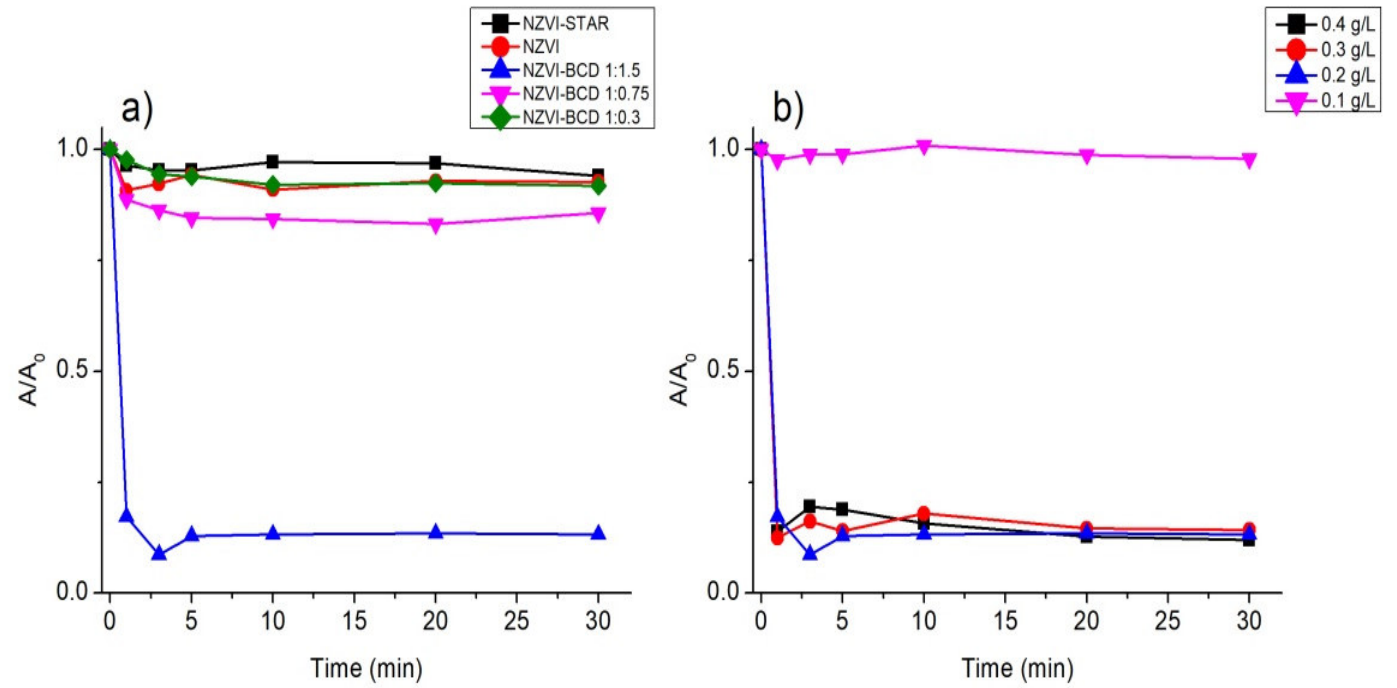

Figure 3 a) Comparison of different NZVI types for the hydrogenation of 4-NP (conditions: $0.2 \mathrm{~g} / \mathrm{L}$ of NZVI and $0.12 \mathrm{mM}$ of 4-NP; T: $25^{\circ} \mathrm{C}$ ) and b) reduction of 4-NP by $\beta C D-N Z V I$ (ratio $1: 1.5$ conditions: $0.12 \mathrm{mM}$ of $\left.4-\mathrm{NP} ; \mathrm{T}: 25^{\circ} \mathrm{C}\right)$ 
For a better comparison of the reduction activity, it was chosen to compare the $\beta C D-N Z V I$ synthesized in three different ratios $(1: 1.5,1: 0.75$ and $1: 0.3)$ with a commercial NZVI-STAR and with the bare NZVI (without stabilization). Under the tested condition a better behavior in this process was shown by $\beta C D-N Z V I$ (ratio $1: 1.5)$, at the concentration of $0.2 \mathrm{~g} / \mathrm{L}$, the bare NZVI, NZVI-STAR and $\beta C D-N Z V I(1: 0.75,1: 0.3)$ has not shown an appreciable effect. The enhanced catalytic properties shown by $\beta C D-N Z V I$ confirms our suspicions concerning synergistic effect of $\beta C D$ on the surface of NZVI. The presence of $\beta C D$ could enhance the accessibility of active sites on the nanoparticles by hosting the organic 4-NP in their cavities. The hypothesis that the $\beta C D$ can enhance the hydrogenation of 4-NP has been strengthened by the fact that the average particle size of bare NZVI is smaller in comparison to $\beta C D-N Z V I$ (which normally indicates larger available specific surface area and better catalytic properties). However, the presence of $\beta C D$ on NZVI surface could explain why synthesized $\beta C D-N Z V I$ were more efficient in the degradation process of 4-NP. Nonetheless, further studies are required in order to confirm this hypothesis.

\section{CONCLUSION}

For the first time NZVI particles were successfully synthesized and functionalized with $\beta C D$. Morphology of the particles was studied using SEM and their spherical shape was confirmed. Average particle size of the $\beta C D-$ NZVI composite was found to be $155 \mathrm{~nm}$. Presence of the organic layer on the nanoparticles surface was confirmed by the EDX test. Zeta potential analysis of synthesized nanoparticles indicated their better stability in more alkaline/acidic conditions $(-16 \mathrm{mV},+9 \mathrm{mV})$. However, further research is needed focusing on better stabilization of these nanoparticles. Their catalytic activity was compared with different NZVI's during the reduction of 4-NP and synthesized herein nanoparticles were found to be the most effective in the removal of 4-NP. Further studies are required for understanding the degradation kinetics of organic pollutants by $\beta C D$ NZVI.

\section{ACKNOWLEDGEMENTS}

The research presented in this article was supported by the Internal Grant of the Technical University of Liberec (RISING-STARS; no: 30002)

\section{REFERENCES}

[1] O'CONNOR, George A. Organic compounds in sludge-amended soils and their potential for uptake by crop plants. In: Science of the Total Environment [online]. 1996. ISSN 00489697. Available at: https://doi.org/10.1016/0048-9697(95)05043-4.

[2] CUNDY, Andrew B., Laurence HOPKINSON and Raymond L.D. WHITBY. Use of iron-based technologies in contaminated land and groundwater remediation: A review. Science of the Total Environment [online]. 2008. ISSN 00489697. Available at: https://doi.org/10.1016/j.scitotenv.2008.07.002.

[3] MUKHERJEE, Ritika, Rahul KUMAR, Alok SINHA, Yangdup LAMA and Amal Krishna SAHA. A review on synthesis, characterization, and applications of nano zero valent iron (nZVI) for environmental remediation [online]. 2016. ISSN 15476537. Available at: https://doi.org/10.1080/10643389.2015.1103832.

[4] HOSSEN, Sarwar, M. Khalid HOSSAIN, M. K. BASHER, M. N.H. MIA, M. T. RAHMAN and M. Jalal UDDIN. Smart nanocarrier-based drug delivery systems for cancer therapy and toxicity studies: A review [online]. 2019. ISSN 20901232. Available at: https://doi.org/10.1016/j.jare.2018.06.005

[5] JORTNER, Joshua and C. N.R. RAO. Nanostructured advanced materials. Perspectives and directions. In: Pure and Applied Chemistry [online]. 2002. ISSN 00334545. Available at: https://doi.org/10.1351/pac200274091491.

[6] MUELLER, Nicole C., Jürgen BRAUN, Johannes BRUNS, Miroslav ČERNÍK, Peter RISSING, David RICKERBY and Bernd NOWACK. Application of nanoscale zero valent iron (NZVI) for groundwater remediation in Europe. Environmental Science and Pollution Research [online]. 2012. ISSN 09441344. Available at: https://doi.org/10.1007/s11356-011-0576-3. 
[7] CRANE, R. A. and T. B. SCOTT. Nanoscale zero-valent iron: Future prospects for an emerging water treatment technology [online]. 2012. ISSN 03043894. Available at: https://doi.org/10.1016/j.jhazmat.2011.11.073.

[8] SHU, Hung Yee, Ming Chin CHANG, Hsing Hung YU and Wang Hung CHEN. Reduction of an azo dye Acid Black 24 solution using synthesized nanoscale zerovalent iron particles. Journal of Colloid and Interface Science [online]. 2007. ISSN 00219797. Available at: https://doi.org/10.1016/j.jcis.2007.04.071.

[9] LIU, Wenbo, Nora B. SUTTON, Huub H.M. RIJNAARTS and Alette A.M. LANGENHOFF. Pharmaceutical removal from water with iron- or manganese-based technologies: A review. Critical Reviews in Environmental Science and Technology [online]. 2016. ISSN 15476537. Available at: https://doi.org/10.1080/10643389.2016.1251236.

[10] BERND, Nowack. Pollution Prevention and Treatment Using Nanotechnology. In: Nanotechnology [online]. 2010. Available at: https://doi.org/10.1002/9783527628155.nanotech010.

[11] MÜLLER, Nicole C, Esther LÖBEL and Peter RISSING. Remediation with nano-iron - state of the technology. Germany: Altlasten Spektrum, (2006). 2:75-83.

[12] JOINT RESEARCH CENTRE. Report from the Workshop on Nanotechnologies for Environmental Remediation [online]. Ispra [viewed 2019-09-10] Available from: http://www.nanowerk.com/nanotechnology/reports/reportpdf/report101.pdf.

[13] O'CARROLL, Denis, Brent SLEEP, Magdalena KROL, Hardiljeet BOPARAI and Christopher KOCUR. Nanoscale zero valent iron and bimetallic particles for contaminated site remediation. Advances in Water Resources [online]. 2013. ISSN 03091708. Available at: https://doi.org/10.1016/j.advwatres.2012.02.005.

[14] HE, Feng and Dongye ZHAO. Preparation and characterization of a new class of starch-stabilized bimetallic nanoparticles for degradation of chlorinated hydrocarbons in water. Environmental Science and Technology [online]. 2005. ISSN 0013936X. Available at: https://doi.org/10.1021/es048743y.

[15] PADIL VINOD, Vellora Thekkae, Stanisław WACŁAWEK, Chandra SENAN, Jaroslav KUPČíK, Kristýna PEŠKOVÁ, Miroslav ČERNÍK and H. M. SOMASHEKARAPPA. Gum karaya (Sterculia urens) stabilized zerovalent iron nanoparticles: characterization and applications for the removal of chromium and volatile organic pollutants from water. RSC Advances [online]. 2017. ISSN 20462069. Available at: https://doi.org/10.1039/c7ra00464h.

[16] CIRTIU, Ciprian M., Trishikhi RAYCHOUDHURY, Subhasis GHOSHAL and Audrey MOORES. Systematic comparison of the size, surface characteristics and colloidal stability of zero valent iron nanoparticles pre- and post-grafted with common polymers. Colloids and Surfaces A: Physicochemical and Engineering Aspects [online]. 2011. ISSN 18734359. Available at: https://doi.org/10.1016/j.colsurfa.2011.09.011.

[17] SIKDER, Md Tajuddin, Yoshihiro MIHARA, Md Shariful ISLAM, Takeshi SAITO, Shunitz TANAKA and Masaaki KURASAKI. Preparation and characterization of chitosan-caboxymethyl- $\beta$-cyclodextrin entrapped nanozero-valent iron composite for $\mathrm{Cu}$ (II) and Cr (IV) removal from wastewater. Chemical Engineering Journal [online]. 2014. ISSN 13858947. Available at: https://doi.org/10.1016/j.cej.2013.09.093.

[18] BERGE, Nicole D. and C. Andrew RAMSBURG. Oil-in-water emulsions for encapsulated delivery of reactive iron particles. Environmental Science and Technology [online]. 2009. ISSN 0013936X. Available at: https://doi.org/10.1021/es900358p.

[19] SALEH, Navid, Tanapon PHENRAT, Kevin SIRK, Bruno DUFOUR, Jeongbin OK, Traian SARBU, Krzysztof MATYJASZEWSKI, Robert D. TILTON and Gregory V. LOWRY. Adsorbed triblock copolymers deliver reactive iron nanoparticles to the oil/water interface. Nano Letters [online]. 2005. ISSN 15306984. Available at: https://doi.org/10.1021/nl0518268.

[20] SETIJADI, Eki, Lei TAO, Jingquan LIU, Zhongfan JIA, Cyrille BOYER and Thomas P. DAVIS. Biodegradable star polymers functionalized with $\beta$-cyclodextrin inclusion complexes. Biomacromolecules [online]. 2009. ISSN 15257797. Available at: https://doi.org/10.1021/bm900646g.

[21] CHATJIGAKIS, Alexis K., Cecile DONZÉ, Anthony W. COLEMAN and Philippe CARDOT. Solubility Behavior of $\beta$-Cyclodextrin in Water/Cosolvent Mixtures. Analytical Chemistry [online]. 1992. ISSN 15206882. Available at: https://doi.org/10.1021/ac00038a022.

[22] LI, Jie, Changlun CHEN, Ying ZHAO, Jun HU, Dadong SHAO and Xiangke WANG. Synthesis of water-dispersible Fe3O4ß-cyclodextrin by plasma-induced grafting technique for pollutant treatment. Chemical Engineering Journal [online]. 2013. ISSN 13858947. Available at: https://doi.org/10.1016/j.cej.2013.06.016. 
[23] MURAI, Shoji, Satoshi IMAJO, Yasuhiro TAKASU, Keiko TAKAHASHI and Kenjiro HATTORI. Removal of phthalic acid esters from aqueous solution by inclusion and adsorption on $\beta$-cyclodextrin. Environmental Science and Technology [online]. 1998. ISSN 0013936X. Available at: https://doi.org/10.1021/es970463d.

[24] EVANS, Christopher H., Morgan PARTYKA and Jan VAN STAM. Naphthalene complexation by $\beta$-cyclodextrin: Influence of added short chain branched and linear alcohols. Journal of Inclusion Phenomena. 2000. ISSN 09230750.

[25] ORPRECIO, Ricardo and Christopher H. EVANS. Polymer-Immobilized Cyclodextrin Trapping of Model Organic Pollutants in Flowing Water Streams. Journal of Applied Polymer Science [online]. 2003. ISSN 00218995.

Available at: https://doi.org/10.1002/app.12818.

[26] WANG, Manlin, Guodong FANG, Peng LIU, Dongmei ZHOU, Chen MA, Dongju ZHANG and Jinhua ZHAN. Fe3O4@ß-CD nanocomposite as heterogeneous Fenton-like catalyst for enhanced degradation of 4-chlorophenol (4-CP). Applied Catalysis B: Environmental [online]. 2016. ISSN 09263373. Available at: https://doi.org/10.1016/j.apcatb.2016.01.071.

[27] BARUAH, Bharat, Gregory J. GABRIEL, Michelle J. AKBASHEV and Matthew E. BOOHER. Facile synthesis of silver nanoparticles stabilized by cationic polynorbornenes and their catalytic activity in 4-nitrophenol reduction. Langmuir [online]. 2013. ISSN 07437463. Available at: https://doi.org/10.1021/la305068p.

[28] KALANTARI, Katayoon, Amalina Binti Muhammad AFIFI, Saadi BAYAT, Kamyar SHAMELI, Samira YOUSEFI, Norrashidah MOKHTAR and Alireza KALANTARI. Heterogeneous catalysis in 4-nitrophenol degradation and antioxidant activities of silver nanoparticles embedded in Tapioca starch. Arabian Journal of Chemistry [online]. 2016. ISSN 18785352. Available at: https://doi.org/10.1016/j.arabjc.2016.12.018.

[29] GREENWOOD, R. and K. KENDALL. Selection of Suitable Dispersants for Aqueous Suspensions of Zirconia and Titania Powders using Acoustophoresis. Journal of the European Ceramic Society. 1999. ISSN 09552219.

[30] WISSING, S. A., O. KAYSER and R. H. MÜLLER. Solid lipid nanoparticles for parenteral drug delivery. Advanced Drug Delivery Reviews [online]. 2004. ISSN 0169409X. Available at: https://doi.org/10.1016/j.addr.2003.12.002.

[31] JACOBS, C., O. KAYSER and R. H. MÜLLER. Nanosuspensions as a new approach for the formulation for the poorly soluble drug tarazepide. International Journal of Pharmaceutics [online]. 2000. ISSN 03785173. Available at: https://doi.org/10.1016/S0378-5173(99)00412-3.

[32] HONARY, Soheyla and Foruhe ZAHIR. Effect of zeta potential on the properties of nano-drug delivery systems A review (Part 2). Tropical Journal of Pharmaceutical Research [online]. 2013. ISSN 15965996. Available at: https://doi.org/10.4314/tipr.v12i2.20.

[33] BERG, J. Michael, Amelia ROMOSER, Nivedita BANERJEE, Rema ZEBDA and Christie M. SAYES. The relationship between $\mathrm{pH}$ and zeta potential of $\sim 30 \mathrm{~nm}$ metal oxide nanoparticle suspensions relevant to in vitro toxicological evaluations. Nanotoxicology [online]. 2009. ISSN 17435390. Available at: https://doi.org/10.3109/17435390903276941.

[34] LIN, Fang Hsin and Ruey An DOONG. Highly efficient reduction of 4-nitrophenol by heterostructured goldmagnetite nanocatalysts. Applied Catalysis A: General [online]. 2014. ISSN 0926860X. Available at: https://doi.org/10.1016/j.apcata.2014.08.013.

[35] LIU, Chang, Daming YONG, Dengbin YU and Shaojun DONG. Cell-based biosensor for measurement of phenol and nitrophenols toxicity. Talanta [online]. 2011. ISSN 00399140. Available at: https://doi.org/10.1016/j.talanta.2011.02.006.

[36] LI, Jun, Qi LIU, Qing qing JI and Bo LAI. Degradation of p-nitrophenol (PNP) in aqueous solution by Fe0-PM-PS system through response surface methodology (RSM). Applied Catalysis B: Environmental [online]. 2017. ISSN 09263373. Available at: https://doi.org/10.1016/j.apcatb.2016.07.026.

[37] ZHANG, Yonghui, Meiyan SONG, Xiaoli RUI, Shaoxia PU, Yansen LI and Chun Mei LI. Supplemental dietary phytosterin protects against 4-nitrophenol-induced oxidative stress and apoptosis in rat testes. Toxicology Reports [online]. 2015. ISSN 22147500. Available at: https://dx.doi.org/10.1016/j.toxrep.2015.04.007.

[38] XIONG, Zhaokun, Heng ZHANG, Wenchao ZHANG, Bo LAI and Gang YAO. Removal of nitrophenols and their derivatives by chemical redox: A review [online]. 2019. ISSN 13858947. Available at: https://doi.org/10.1016/j.cej.2018.11.111. 
[39] EICHENBAUM, G., M. JOHNSON, D. KIRKLAND, P. O'NEILL, S. STELLAR, J. BIELAWNE, R. DEWIRE, D. AREIA, S. BRYANT, S. WEINER, D. DESAI-KRIEGER, P. GUZZIE-PECK, David C. EVANS and A. TONELLI. Assessment of the genotoxic and carcinogenic risks of p-nitrophenol when it is present as an impurity in a drug product. Regulatory Toxicology and Pharmacology [online]. 2009. ISSN 02732300. Available at: https://doi.org/10.1016/i.yrtph.2009.05.018.

[40] CHEN, Jiaqin, Meiyan SONG, Yansen LI, Yonghui ZHANG, Kazuyoshi TAYA and Chun Mei LI. The effect of phytosterol protects rats against 4-nitrophenol-induced liver damage. Environmental Toxicology and Pharmacology [online]. 2016. ISSN 18727077. Available at: https://doi.org/10.1016/i.etap.2015.12.011.

[41] ARORA, Pankaj Kumar, Alok SRIVASTAVA and Vijay Pal SINGH. Bacterial degradation of nitrophenols and their derivatives [online]. 2014. ISSN 18733336. Available at: https://doi.org/10.1016/j.jhazmat.2013.12.011.

[42] SILVESTRI, Daniele, Stanisław WACŁAWEK, Bartomiej SOBEL, Rafael TORRES-MENDIETA, Vít NOVOTNÝ, Nhung H.A. NGUYEN, Alena ŠEVCUீ, Vinod V.T. PADIL, Jana MÜLLEROVÁ, Martin STUCHLÍK, Marco Petrangeli PAPINI, Miroslav ČERNÍK and Rajender S. VARMA. A poly(3-hydroxybutyrate)-chitosan polymer conjugate for the synthesis of safer gold nanoparticles and their applications. Green Chemistry [online]. 2018. ISSN 14639270. Available at: https://doi.org/10.1039/c8gc02495b.

[43] WUNDER, Stefanie, Frank POLZER, Yan LU, Yu MEI and Matthias BALLAUFF. Kinetic analysis of catalytic reduction of 4-nitrophenol by metallic nanoparticles immobilized in spherical polyelectrolyte brushes. Journal of Physical Chemistry C [online]. 2010. ISSN 19327447. Available at: https://doi.org/10.1021/jp101125j.

[44] GANGULA, Abilash, Ramakrishna PODILA, Ramakrishna M, Lohith KARANAM, Chelli JANARDHANA and Apparao M. RAO. Catalytic reduction of 4-nitrophenol using biogenic gold and silver nanoparticles derived from breynia rhamnoides. Langmuir [online]. 2011. ISSN 07437463. Available at: https://doi.org/10.1021/la2034559. 